Int. J. Electrochem. Sci., 14 (2019) 9080 - 9091

\title{
Zinc Layered Hydroxide-Sodium Dodecyl Sulphate-Isoprocarb Modified Multiwalled Carbon Nanotubes as sensor for Electrochemical Determination of Dopamine in Alkaline Medium
}

\author{
Mohamad Syahrizal Ahmad ${ }^{1,2, *}$, Illyas Md Isa, ${ }^{1,2, *}$, Norhayati Hashim ${ }^{1,2}$, Mohamad Idris Saidin ${ }^{1,2}$, \\ Suyanta M. Si ${ }^{3}$, Rahadian Zainul ${ }^{4}$, Alizar Ulianas ${ }^{4}$, Siriboon Mukdasai ${ }^{5}$ \\ ${ }^{1}$ Nanotechnology Research Centre, Faculty of Science and Mathematics, Universiti Pendidikan Sultan \\ Idris, 35900 Tanjong Malim, Perak Darul Ridzuan, Malaysia. \\ ${ }^{2}$ Department of Chemistry, Faculty of Science and Mathematics, Universiti Pendidikan Sultan Idris, \\ 35900 Tanjong Malim, Perak Darul Ridzuan, Malaysia. \\ ${ }^{3}$ Department of Chemistry Education, Faculty of Mathematics and Natural Science, Yogyakarta State \\ University, Yogyakarta, Indonesia. \\ ${ }^{4}$ Department of Chemistry, Faculty of Mathematics and Natural Science, Universitas Negeri Padang, \\ West Sumatera 25171, Indonesia \\ ${ }^{5}$ Department of Chemistry, Faculty of Science, Khon Kaen University, Khon Kaen 40002, Thailand \\ *E-mail: syahrizal@ fsmt.upsi.edu.my and illyas@ fsmt.upsi.edu.my
}

doi: $10.20964 / 2019.09 .54$

Received: 12 May 2019 / Accepted: 9 July 2019 / Published: 5 August 2019

A sensitive and selective electrochemical sensor for detection of dopamine (DOP) using zinc layered hydroxide-sodium dodecyl sulphate-isoprocarb (ZLH-SDS-I)/multiwalled carbon nanotubes (MWCNT) in $100 \mathrm{mM}$ phosphate buffer solution (PBS) and at the $\mathrm{pH} 8.0$ was developed. The morphology and electrochemistry properties of ZLH-SDS-I/MWCNT nanocomposites were characterized using square wave voltammetry (SWV), transmission electron microscopy (TEM), cyclic voltammetry (CV), electrochemical impedence spectroscopy (EIS) and scanning electron microscopy (SEM). Under optimized conditions, the linear analytical curve for determination of dopamine was 1.0 $\mu \mathrm{M}$ to $0.3 \mathrm{mM}$ with the detection limit of $0.43 \mu \mathrm{M}$. Besides that, the proposed sensor also exhibited good selectivity, stability, sensitivity and was found to be applicable for dopamine detection in the commercial dopamine hydrochloride injection samples.

Keywords: Dopamine, zinc layered hydroxide-sodium dodecyl sulphate-isoprocarb, square wave voltammetry, multiwalled carbon nanotubes. 


\section{FULL TEXT}

(C) 2019 The Authors. Published by ESG (www.electrochemsci.org). This article is an open access article distributed under the terms and conditions of the Creative Commons Attribution license (http://creativecommons.org/licenses/by/4.0/). 